\title{
Diseases and partial mortality in Montastraea annularis species complex in reefs with differing environmental conditions (NW Caribbean and Gulf of México)
}

\author{
Eric Jordán-Dahlgren*, Miguel Angel Maldonado, Rosa Elisa Rodríguez-Martínez
}

Instituto de Ciencias del Mar y Limnología, Universidad Nacional Autonoma de Mexico (UNAM), Apartado Postal 1152, 77500 Cancún, Quintana Roo, Mexico

\begin{abstract}
We documented the prevalence of diseases, syndromes and partial mortality in colonies of the Montastraea annularis species complex on 3 reefs, and tested the assumption that a higher prevalence of these parameters occurs when reefs are closer to point-sources of pollution. One reef was isolated from the impact of local factors with the exception of fishing, 1 potentially influenced by local industrial pollutants, and 1 influenced by local urban pollution. Two reefs were surveyed in 1996 and again in 2001 and 1 in 1998 and again in 2001. In 2001, colonies on all reefs had a high prevalence of the yellow-band syndrome and a relatively high degree of recent partial mortality, while the prevalence of black-band and white-plague diseases was low although a new sign, that we named the thin dark line, had relatively high prevalence in all reefs. As no direct relationship was found between disease prevalence and local environmental quality, our results open the possibility that regional and/or global factors may already be playing an important role in the prevalence of coral disease in the Caribbean, and contradict the theory that coral disease prevalence is primarily related to local environmental degradation. Reasons that may partially explain these findings are the high level of potential pathogen connectivity within the Caribbean as a result of its circulation patterns coupled to the large land-derived pollutants and pathogens input into this Mediterranean sea, together with the surface water warming effects which stress corals and enhance pathogen activity.
\end{abstract}

KEY WORDS: Coral $\cdot$ Disease $\cdot$ Prevalence $\cdot$ Mortality $\cdot$ Local impacts $\cdot$ Regional impacts

\section{INTRODUCTION}

It is widely accepted that the numbers and prevalence of infectious coral diseases are increasing and that they have become widespread in recent decades, and the Caribbean Sea is now considered a 'hot spot' of coral disease (Harvell et al. 1999, Green \& Bruckner 2000, Daszak et al. 2001, Porter et al. 2001). The major concern about the increased prevalence of these diseases is that many are multispecific, able to spread rapidly, and lethal. Reef building corals of the genus Acropora have already been decimated by diseases in the Caribbean (Gladfelter 1982, Aronson \& Precht 2001). Other key framework corals such as the Montastraea annularis species complex, also appear to be threatened, as a drastic reduction in the relative abun- dance of these species has already been documented for some Caribbean reefs (Dustan 1999, Woodley et al. 2000, Cervino et al. 2001). More importantly, the $M$. annularis species complex appears to be affected by a high number of diseases and syndromes, among them, black-band, white-plague diseases and the yellowblotch (yellow-band) syndrome (Dustan 1977, Antonius 1981, Rützler \& Santavy 1983, Richardson et al. 1998, Santavy et al. 1999), making it highly vulnerable. Several reports also indicate a population decrease in these species due to bleaching and unusual cold-water episodes (Cervino et al. 2001, Ginsburg et al. 2001, Porter et al. 2001).

Deterioration of environmental quality is now considered one of the main causes for the increased prevalence and virulence of diseases, and that local, 
regional and global anthropogenic impacts are a likely cause of this deterioration (Harvell et al. 1999, Daszak et al. 2001). Of particular concern is that local and point-source factors which degrade environmental quality (i.e. sewage contamination, nutrient enrichment, toxic substances, siltation) may have an acute effect on coral disease prevalence and virulence (Harvell et al. 1999, Porter et al. 2001, Kuta \& Richardson 2002), either by lowering host resistance to infection by pathogens (Alker et al. 2001) and/or by reducing the ability of the host to contain the infection (Kim \& Harvell 2002). Considering that urban and tourist developments are now rapidly spreading in the coastal zone of reef-fringed areas (Erdmann 1997), local threats to coral health will become increasingly important. These local threats are also linked to global climate change and global warming, which are of great concern in respect to coral health, because they are stressors of coral symbioses (Brown 1997), and also are stimulators of growth and activity for several coral pathogens (Kushmaro et al. 1996, Alker et al. 2001).

This study quantified the prevalence of diseases, syndromes and partial mortality in colonies of the Montastraea annularis species complex that occur in reefs distant from, and close to, population and industrial centers. Our objective was to test the assumption that colonies of this species complex suffer higher prevalence of disease and higher partial mortality when reefs are closer to human activities. We also compared the prevalence of diseases and syndromes over a 3 to 5 yr period to determine if there was an increase in their prevalence related to the proximity of sources of environmental impact.

\section{MATERIALS AND METHODS}

Study sites. The study was conducted on 2 reefs at the Campeche Bank in the SE Gulf of México - Triángulos Este (TE) and Cayos Arcas (CA); and 1 reef on the NE coast of the Yucatan Peninsula - Puerto Morelos (PM) (Fig. 1). All 3 reefs are at approximately latitude $20^{\circ} \mathrm{N}$ (Fig. 1), and thus have a similar oceanic climate, mostly determined by trade winds and occasionally hurricanes in summer, and northern cold polar fronts in winter.

The Gulf of México reefs, TE and CA, are small $\left( \pm 10 \mathrm{~km}^{2}\right)$ but well developed reefs with clearly defined zonation and a rich coral community; as in Caribbean reefs, Acroporids and massive corals of the Montastraea species complex are the dominant reef builders (Jordán-Dahlgren \& Rodríguez-Martínez, 2003). These reefs are located on the western edge of the Campeche Bank, more than $150 \mathrm{~km}$ off the coast, far from any population center and direct terrestrial influence. These reefs are outside the main surface circulation patterns of the Gulf of México (Vukovich \& Crissman 1986, Jordán-Dahlgren 2002). Surface water circulation in the reef's area is induced by local windforcing over the Campeche Bank (Sturges 1993), and flows mostly south and westward, occasionally coupling in the shelf's edge (nearby to the reefs position) with a westbound jet-current originated by surface anomalies induced by detached rings of the loopcurrent (Vidal et al. 1999). Both reefs were severely affected by hurricanes 'Roxanne' and 'Opal' in 1995, and Acroporid populations have been decimated in these reefs, probably due to white-band disease (see Table 1).

Local anthropogenic activities in TE are restricted to fishing from visiting boats, as no human settlements of any kind are possible in the small sand cays. To our knowledge, no water quality data series are available for the TE area. In contrast, CA is located approximately $4 \mathrm{~km}$ upstream of a oil-distribution platform where large crude-tankers are filled. Support vessels, for the filling rig operation and maintenance of oilpipes, anchor on the reef's lagoon using mooring buoys. In the past, these vessels threw all sorts of trash into the lagoon, but this practice has now been stopped. We have witnessed oil spills when filling lines are connected/disconnected from the tankers; but in those occasions the oil drifted away from the reef. However, the extent and frequency of these or other spills are unknown to us as the information is classified, as are water quality and pollutants data. Access to CA is restricted, because of the oil producing facility, so the reef is indirectly protected from other anthro-

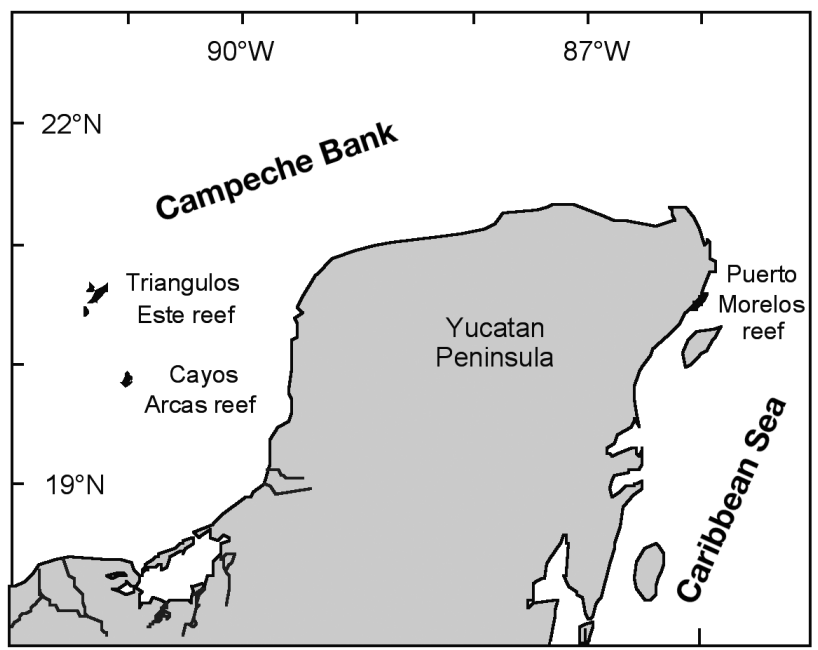

Fig. 1. Location of the 3 coral reefs surveyed in this study: Cayos Arcas and Triángulos Este reefs on Campeche Bank and Puerto Morelos reef in Mexican Caribbean. Reefs are not drawn to scale 
pogenic potential impacts. At present PEMEX (Petroleos Mexicanos) is implementing specific protection measures to reduce the potential impact of its own activities on the reef. On the main island a small military outpost (10 people) exists and small boat fishermen are allowed to spend the night during the fishing season (in summer mostly), but they are not allowed to fish on the reef. No waste treatment facilities exist.

In contrast to the oceanic Campeche Bank reefs, PM is a barrier-like reef running parallel to the shore at a distance of 0.6 to $2 \mathrm{~km}$, fringing the small village of Puerto Morelos, on the NE Yucatán coast. The Yucatán current, a major branch of the western Caribbean Sea surface circulation, flows northward along the short shelf, and during the trade-wind season superficial waters from that currents are transported into the reef area. Occasionally friction-induced upwelling brings cooler waters in to the shelf and the reef area (Merino, 1997). Potentially the Yucatán current is able to transport pollutants into PM from the nearby southern large cities of Cozumel and Playa del Carmen, as well as from other large settlements along the coast, where water-treatment is insufficient or absent, because only hotels tend to have functional and modern water-treatment facilities. Locally, direct transport of land-derived pollutants is not apparently important because the Yucatan peninsula is a karstic platform (Ward 1985), rivers are absent and terrestrial run-off is low. However, the village of PM has a population of about 3000 and there is no water-treatment facility (except in some hotels), and there is an estimated annual number of 35000 visitors. Additionally, pig-farms operate inland. Therefore, aside from seepage through coastal sediments, during the rainy season accumulated pollutants may be carried to offshore waters by underwater springs. On the other hand, trade wind induced waterpilling, waves and tides induce an active water circulation in the lagoon, as well as exchange with open waters. Fishing in PM is allowed on the fore-reef and tourism is controlled.

PM was severely affected in 1988 by hurricane 'Gilbert', but recovery is well underway at present, and Acropora palmata stands are once again an important component of the coral biota of this reef (JordánDahlgren \& Rodríguez-Martínez 1998). The 1998 global bleaching event had little or no impact on mortality of Montastraea annularis complex colonies in PM, whereas it is not known to what extent TE and CA colonies were affected. Other Caribbean-wide natural catastrophes such as the Diadema antillarum die-off affected all surveyed reefs intensely (E. JordánDahlgren pers. obs.).

Methods. We surveyed benthic community structure on TE and CA in 1996 and again in 2001, and on PM in 1998 and again in 2001. The surveys used high- resolution video transects (except in PM 1998 where measurements were made directly by SCUBA divers), which enabled clear detection of diseases, syndromes and partial mortality. These surveys were not designed to address the change in fixed sampling sites, but the video footage did allow us to analyze coral colony condition at the time of the surveys. For this study, we determined the prevalence of diseases and syndromes affecting species of the Montastraea annularis complex as well as the degree of partial mortality of the colony. To compare the same habitat types we used data from sampling sites in shallow and protected areas (depth range between 1.5 and $5.0 \mathrm{~m}$ ) where species of the $M$. annularis complex are common. No attempt was made to differentiate between the species within the $M$. annularis complex (mostly $M$. annularis and $M$. faveolata) because in most cases positive identification of the abundant small-sized colonies (less than $25 \mathrm{~cm}^{2}$ ), cannot be reliably made from video-shots.

The areas surveyed in 2001 corresponded to 3 separate sites on $\mathrm{TE}$ and $\mathrm{CA}$ that were chosen from UNAM'S (Universidad Nacional Autonoma de México) Reef System Laboratory video library for the 1996 surveys. In 1996, each site was surveyed using 2 parallel $20 \mathrm{~m}$ long video transects (0.6 m wide). In 2001, 6 randomly dispersed sites were sampled in TE and 17 in CA. Each site consisted of 5 to 10 randomly parallel (1 to $10 \mathrm{~m}$ apart), $10 \mathrm{~m}$ long video-transect $(0.4 \mathrm{~m}$ wide); 39 transects in TE and 42 in CA contained colonies of the Montastraea annularis species complex. The 1998 survey of the PM reef consisted of 3 sites, each comprising a single $50 \times 2 \mathrm{~m}$ quadrat, and diseases were identified directly. In 2001, the survey of PM also included three $10 \mathrm{~m}$ diameter circles on sites randomly placed along the protected area of the reef. Each colony within the circle was completely filmed with appropriate scale marks and its relative position was entered on a geo-reference map. All samplings were carried out in the summer, when diseases flourish (Bruckner \& Bruckner 1997, Bruckner et al. 1997, Kuta \& Richardson 2002).

In all video surveys, the camera-to-surface distance was controlled by means of a projecting aluminum rod, ending in a horizontal scale; image resolution with wide-angle lenses at this distance was about $1 \mathrm{~mm}$. Video recordings were digitized and the still images were analyzed using SigmaScan Pro Version 4.0 (SPSS, Chicago) for measuring areas of live tissue and recent necrosis (exposed skeleton not covered by turf or sediment and where corallites are not eroded). Because we were interested in estimating the degree of partial mortality relative to the original colony, all patches of tissue belonging to the same species on a given corallum were counted as 1 colony, even when there was no live tissue continuity. Colonies without 
evident signs of diseases/syndromes, but which showed recent mortality were classified as necrotic colonies.

To detect basic trends in the relationship between local environmental quality and disease prevalence, we made a simple relative impact matrix of local and external (global/regional) impacts (Table 1). The purpose of the impact matrix was to rank the surveyed reefs in terms of environmental quality and to compare this ranking with the quantitative results on prevalence of diseases and syndromes. It was considered that if the prevalence of diseases or syndromes is positively correlated with decreasing local environmental quality, then external factors would make a relatively low contribution to the prevalence of diseases and syndromes. Rating of the relative impact matrix were assigned subjectively and due to the lack of reliable environmental quality data series, we utilized a crude approach based upon reef proximity to point-sources of potential anthropogenic impact (the PM reef $<2 \mathrm{~km}$ from shore; the CA reef is $\sim 5 \mathrm{~km}$ upstream from the oil platform, and the TE reef is $>90 \mathrm{~km}$ away from any pollution source). The proximity criteria to estimate relative local environmental deterioration by pollutants

Table 1. Relative impact matrix of local and external factors on reefs studied. Values from 0 (no effect) to 3 (maximum effect) were assigned subjectively to allow comparison between reefs. TE: Triángulos Este; CA: Cayos Arcas; PM: Puerto Morelos. nd: no data. Fishing: mostly high value carnivores targeted in these reefs; Oceanic pollutants: trash and substances transported into these reefs by western Caribbean superficial currents; Land pollutants: trash and substances carried by runoff and underwater springs; Hurricanes: present condition of reefs after recovery from hurricane impacts; Bleaching: not known if bleaching has occurred on CA and TE

\begin{tabular}{|lcccc|}
\hline Factors & \multicolumn{3}{c|}{ Reefs } & Relative impact \\
& TE CA PM & rank \\
\hline Local & & & & \\
Fishing & 3 & 1 & 2 & \\
Tourism & 0 & 1 & 2 & \\
Urban pollutants & 0 & 1 & 2 & \\
Industrial pollutants & 0 & 2 & 0 & \\
Total & 3 & 5 & 6 & TE $<$ CA $<$ PM \\
External & & & & \\
Allochthonous & & & & \\
Oceanic pollutants & 1 & 1 & 1 & \\
Land pollutants & 0 & 0 & 1 & \\
Total & 1 & 1 & 2 & TE $=$ CA $<$ PM \\
Natural & & & & \\
Acroporid demise & 3 & 3 & 1 & \\
Diadema demise & 3 & 3 & 3 & \\
Macroalgae overgrowth & 1 & 1 & 1 & \\
Hurricanes & 3 & 3 & 2 & \\
Bleaching & nd & nd & 1 & \\
Total & 10 & 10 & 8 & TE $=$ CA $>$ PM \\
\hline
\end{tabular}

were based on the fact that, due to horizontal and vertical advection, dilution of suspended particles and solutes increases with increasing distance and/or transport interval between the source and the receiving area (i.e. see Cowen et al. 2000). The 'external factors' category was divided into 2 sub-categories, allochthonous pollutants and 'natural' events. The ratings of the 'natural' events such as hurricanes, keyspecies die-offs and bleaching events were based on the effects of these events on the reefs, and therefore in the case of hurricanes the assigned values reflect the recovery interval, as well as the intensity of the storm (Table 1). The 'natural impacts' category was included to provide a context for and comparison with local effects.

\section{RESULTS}

Although the sampling effort differed between surveys, the sampling sites were randomly spread over the reefs and the number of colonies sampled per reef at each survey was relatively high (Table 2), allowing us to make some basic comparisons. The prevalence of diseases or syndromes affecting colonies of the Montastraea annularis species complex, increased considerably over the 3 and $5 \mathrm{yr}$ monitoring periods on all reefs: from 2 to $37 \%$ on TE, from 4 to $34 \%$ on CA, and from 0 to $26 \%$ in PM (Table 2). This increase was due to the proliferation of the yellow-band syndrome rather than to significant changes in other coral diseases.

In the 1996 survey, the yellow-band syndrome was not recorded on TE and only 5 colonies were affected by this syndrome at a single site on CA, while no colonies appeared to be affected at PM in 1998. While it cannot be excluded that the syndrome was present at PM in 1998 (it could have been masked by a bleaching episode), tissue necrosis was found in only $9.4 \%$ of the colonies sampled. In contrast, in the 2001 surveys, the syndrome was recorded at 5 out of 6 sites in TE, 9 out of 17 sites in CA, and at all 3 sites sampled on PM. Therefore, the overall prevalence of the yellow-band syndrome in colonies of the Montastraea annularis species complex increased during the 3 and 5 yr periods from 0 to $35 \%$ on TE, from 3 to $33 \%$ on CA, and from 0 to $22 \%$ on PM (Table 2, Fig. 2). However, variability in the prevalence of this syndrome among transects was high for all surveyed reefs (Fig. 2), and no significant difference was found in mean syndrome prevalence on the 3 reefs sampled in 2001 (1-way ANOVA on arcsine-transformed data: $\mathrm{df}=25 ; \mathrm{F}=$ $0.085 ; \mathrm{p}=0.92$ ).

In 2001 at TE and CA, the number of colonies with yellow-band syndrome was significantly correlated with colony density (TE: $r=0.999, N=6, p<0.001$; CA: 
Table 2. Montastraea annularis species complex number of colonies affected by diseases, syndromes and uncharacterized signs in Cayos Arcas (CA) and Triángulos Este (TE) reefs in 1996 and 2001 and in Puerto Morelos (PM) reef in 1998 and 2001. YBS: yellow-band syndrome; BBD: black-band disease; WPD: white-plague disease; TDL: thin dark line sign; IPS: inter-polyp sediment bundles; Nec: tissue necrosis observed but not related to any of the aforementioned. Relative percentage $=\%$ of number of colonies examined (n) on each reef. ?: not investigated

\begin{tabular}{|c|c|c|c|c|c|c|c|c|c|}
\hline \multirow[t]{2}{*}{ Reef } & \multirow[t]{2}{*}{$\mathrm{n}$} & \multicolumn{4}{|c|}{ Diseases/syndromes } & \multicolumn{4}{|c|}{ Uncharacterized signs } \\
\hline & & YBS & $\mathrm{BBD}$ & WPD & Total & TDL & IPS & $\mathrm{Nec}$ & Total \\
\hline \multicolumn{10}{|c|}{ Triángulos Este } \\
\hline TE96 & 86 & 0 & 0 & $\begin{array}{c}2 \\
(2 \%)\end{array}$ & $\begin{array}{c}2 \\
(2 \%)\end{array}$ & $\begin{array}{c}25 \\
(29 \%)\end{array}$ & 0 & $\begin{array}{c}3 \\
(4 \%)\end{array}$ & $\begin{array}{c}28 \\
(33 \%)\end{array}$ \\
\hline TE01 & 533 & $\begin{array}{c}186 \\
(35 \%)\end{array}$ & $\begin{array}{c}5 \\
(1 \%)\end{array}$ & $\begin{array}{c}8 \\
(2 \%)\end{array}$ & $\begin{array}{c}199 \\
(37 \%)\end{array}$ & $\begin{array}{c}154 \\
(29 \%)\end{array}$ & $\begin{array}{c}1 \\
(0.2 \%)\end{array}$ & $\begin{array}{c}14 \\
(3 \%)\end{array}$ & $\begin{array}{c}169 \\
(32 \%)\end{array}$ \\
\hline \multicolumn{10}{|c|}{ Cayos Arcas } \\
\hline CA96 & 153 & $\begin{array}{c}5 \\
(3 \%)\end{array}$ & $\begin{array}{c}1 \\
(1 \%)\end{array}$ & 0 & $\begin{array}{c}6 \\
(4 \%)\end{array}$ & $\begin{array}{c}44 \\
(29 \%)\end{array}$ & 0 & $\begin{array}{c}2 \\
(1 \%)\end{array}$ & $\begin{array}{c}46 \\
(30 \%)\end{array}$ \\
\hline CA01 & 253 & $\begin{array}{c}84 \\
(33 \%)\end{array}$ & $\begin{array}{c}2 \\
(1 \%)\end{array}$ & 0 & $\begin{array}{c}86 \\
(34 \%)\end{array}$ & $\begin{array}{c}64 \\
(25 \%)\end{array}$ & 0 & $\begin{array}{c}2 \\
(0.8 \%)\end{array}$ & $\begin{array}{c}66 \\
(26 \%)\end{array}$ \\
\hline \multicolumn{10}{|c|}{ Puerto Morelos } \\
\hline PM98 & 212 & 0 & 0 & 0 & 0 & $?$ & $?$ & $\begin{array}{c}19 \\
(9 \%)\end{array}$ & $?$ \\
\hline PM01 & 68 & $\begin{array}{c}15 \\
(22 \%)\end{array}$ & 0 & $\begin{array}{c}3 \\
(4 \%)\end{array}$ & $\begin{array}{c}18 \\
(26 \%)\end{array}$ & $\begin{array}{c}42 \\
(62 \%)\end{array}$ & $\begin{array}{c}17 \\
(25 \%)\end{array}$ & $\begin{array}{c}2 \\
(3 \%)\end{array}$ & $\begin{array}{c}61 \\
(90 \%)\end{array}$ \\
\hline
\end{tabular}

$\mathrm{r}=0.98, \mathrm{~N}=17, \mathrm{p}<0.001)$, and the syndrome was not registered at sites with fewer than 5 colonies. In PM, no significant correlation was found between colony density and the number of colonies affected by the syndrome. These results, together with the apparent absence of the syndrome from sites of low colony density, suggests that at some stage the prevalence of the syndrome may be density-dependent.

In contrast to the yellow-band syndrome patterns, the prevalence of other diseases and syndromes was low. Black-band disease was registered in less than $1 \%$ of the colonies on all reefs at any sampling period, while white-plague disease was not registered in CA at all, and in TE and PM its prevalence was not higher than $3 \%$ during either sampling period (Table 2). In addition, to the above known diseases syndrome, uncharacterized signs (unknown if they cause mortality and what the causative agent is) were relatively important on all surveyed reefs during both sampling periods (Table 2). One such sign was a thin dark line (1 to $5 \mathrm{~mm}$ ) at the boundary of living tissue (Fig. 3A). This sign was observed in almost one-third of the colonies of the Montastraea annularis species complex in TE and CA (and in other scleractinian species as well), whereas in PM more than $60 \%$ of the colonies had it. In all 3 reefs, $>10 \%$ of colonies with the yellow-band syndrome also displayed the thin dark line sign. Preliminary additional observations in late summer at PM indicated that in some, but not all, instances the thin dark line was associated with mortality but unlike the black-band disease, seemed stationary or progressed at a very slow rate $\left(<1 \mathrm{~cm} \mathrm{yr}^{-1}\right)$. Microscopic observations of the thin dark line-affected tissue revealed the presence of cyanobacteria, therefore it is possible that this sign may correspond to an undescribed stage of the black-band disease and if that where the case, then black-band disease would also be an important disease in the surveyed reefs. Another possibility is that of a new undescribed disease, that because of the thinness of the

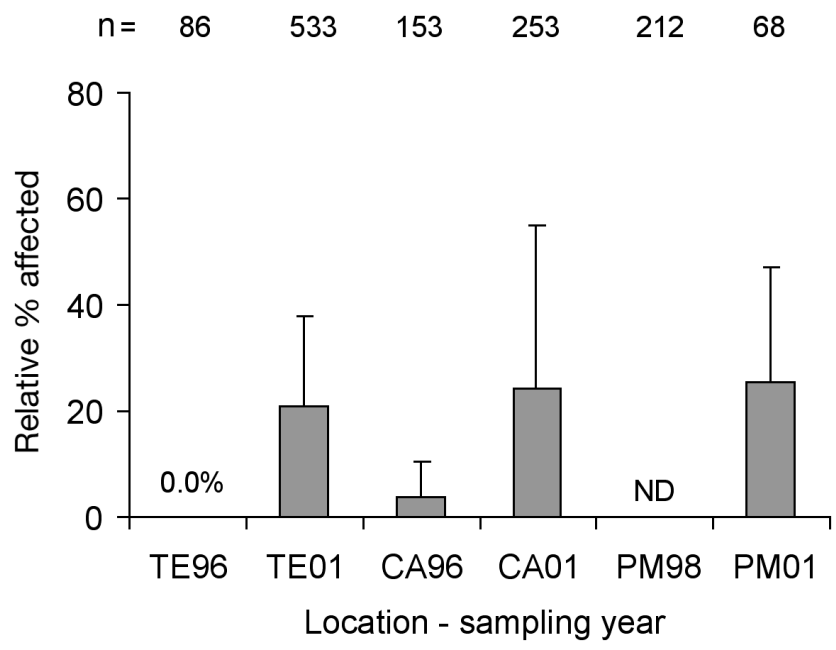

Fig. 2. Montastraea annularis species complex. Relative mean $(+\mathrm{SD})$ percentage of colonies affected by yellow-band syndrome (\% of number of colonies examined, $\mathrm{n}$ ) in Cayos Arcas (CA) and Triángulos Este (TE) reefs in 1996 and 2001 and in Puerto Morelos (PM) reef in 1998 and 2001. ND: no data 

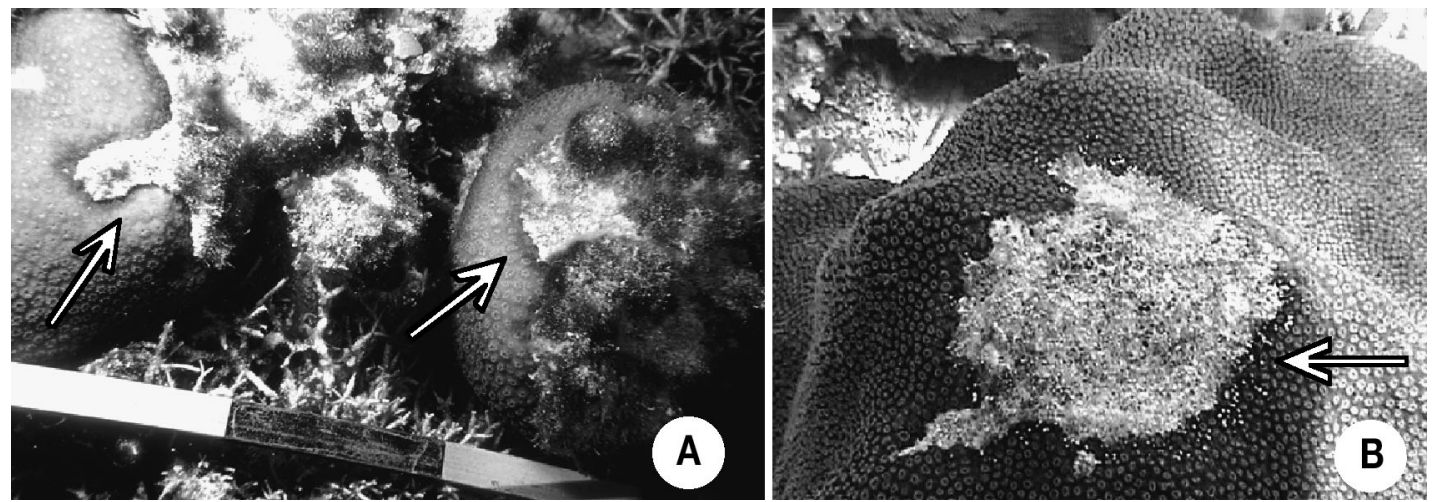

Fig. 3. Montastraea annularis species complex. Colonies in Puerto Morelos reef, Mexico, summer 2001. (A) Thin dark line at boundary of living tissue; (B) inter-polyp sediment (IPS) bundles

affected area reminds of the pink-line syndrome in Porites lutea (Ravindran \& Raghukumar 2002).

Another sign, found in the 2001 surveys, was characterized by the presence of small white bundles of sediment and mucus over live tissue bordering a recently necrotic area. This sign was relatively common in PM during 2001 (25\%) and was also present at TE, but only in a single colony (IPS in Table 2, Fig. 3B). No colonies showed this sign at CA. Microscopic observations of the affected tissue showed mesenterial filaments protruding through the polyp wall (where the bundles occurred) with sediment particles adhering to them; we therefore named them 'inter-polyp sediment' bundles (IPS). Although the tissue affected by inter-polyp sediment bundles surrounded dead areas in the colony, a causal relationship between mortality in those areas and the presence of this sign has not been demonstrated.

The number of colonies of the Montastraea annularis species complex displaying partial mortality increased considerably between 1996 and 2001 from 20.2 to $34.8 \%$ in CA and from 34.9 to $52.3 \%$ in TE. The mean

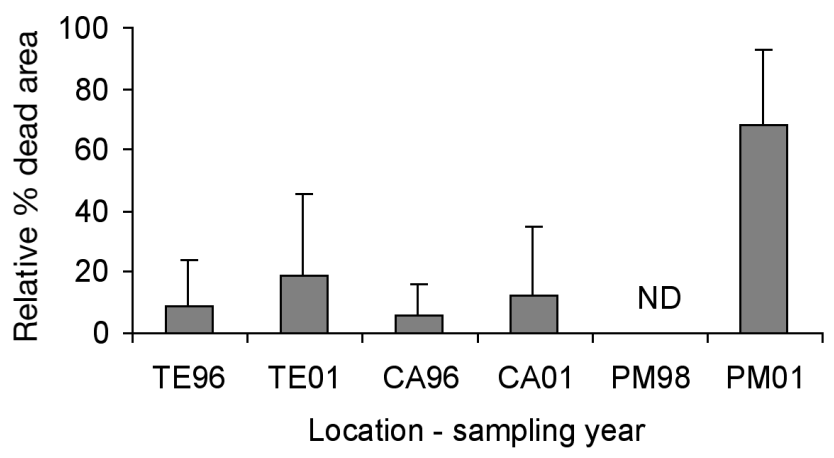

Fig. 4. Montastraea annularis species complex. Percentage $($ mean $+\mathrm{SD})$ dead area in colonies in Cayos Arcas (CA), Triángulos Este (TE) and Puerto Morelos (PM) reefs. Sample sizes in Table 2. ND: no data colony partial mortality (old and recent) of the colonies, also increased from 5.6 to $12.3 \%$ in CA and from 8.5 to 19.1\% in TE between 1996 and 2001 (Fig. 4). No relationship was found between colonies with partial mortality and location on any reef. Tissue loss in these colonies appeared to be related to diseases and syndromes, because colonies with no signs of infection had very low percentages of partial mortality $(<3 \%)$ on all reefs. In the PM 2001 survey, all colonies exhibited partial mortality; however, it was found that 'recent' colony mortality accounted for only $1.7 \%( \pm 5.8 \%)$ of total dead area, while 'old' mortality accounted for $68 \%( \pm 24.5 \%)$. The 'old' mortality areas may have been the cumulative effect of many years, as they exhibited secondary colonization by fleshy macroalgae (species of Dictyota, Halimeda, Lobophora), turf algae, encrusting sponges, gorgonians, and other scleractinian species.

According to the relative impact matrix (Table 1), TE appears to be isolated from the impact of local factors other than fishing, CA is potentially influenced by local industrial pollutants, while PM is potentially influenced by local and regional urban pollution. Non-local pollutants were apparently of minor relative importance and similar for all reefs. 'Natural' impacts did not appear to have a major effect on the prevalence of diseases and syndromes in colonies of the Montastraea annularis species complex on any of the 3 reefs during the observation period. On this basis we would expect higher values of disease prevalence in colonies of the $M$. annularis species complex in PM, lower values in $\mathrm{CA}$ and minimum values in TE. The same pattern would pertain when local and regional or global effects are additive, and also when partial colony mortality arises mainly from diseases and syndromes. We compared these expected trends with the 2001 survey data only, as these had higher replications per sampling site and a widespread distribution of sites at the reefs. 
There was poor agreement between the expected trends in disease prevalence and the observed values. No significant difference was found among the 3 reefs in the prevalence of any of the diseases or yellow-band syndrome (Table 2). Although the prevalence of the yellow-band syndrome was 10 to $15 \%$ higher in CA and TE than in PM, variability at each surveyed reef was large (Fig. 2), and no significant difference was found among the 3 reefs surveyed.

In terms of partial mortality, however, PM showed much higher values than both CA and TE (Fig. 4), but a very high percent of this mortality corresponded to 'old' mortality (i.e. exhibiting secondary colonization of the exposed areas). Therefore, it is not possible to relate this mortality exclusively to the relatively recent increase in prevalence of diseases or syndromes on PM. Also in contrast to the expected trends, partial mortality of colonies on TE was at least as high as that on CA (Fig. 4), even though TE was the only reef surveyed that was isolated from local anthropogenic effects (except for fishing). A better agreement was obtained when comparing the expected trends and the thin dark line and inter-polyp sediment bundles signs. The inter-polyp sediment bundles affected colonies mostly on PM (1 colony had IPS in TE), while the thin dark line sign had a similar prevalence on TE and CA and a higher prevalence on PM (Table 2).

\section{DISCUSSION AND CONCLUSIONS}

The main results of our surveys showed a relatively high prevalence of the yellow-band syndrome and of recent partial mortality in colonies of the Montastraea annularis species complex in 2001 that seemed independent of local environmental quality. Black-band and white-plague diseases had a similar low prevalence in all 3 reefs surveyed, and showed no relationship with local conditions. There was an increase in the prevalence of yellow-band syndrome on the reefs surveyed during the 3 and 5 yr observation periods. While this increase could not be clearly demonstrated because of differences in sampling effort between the survey periods, this trend is not unlike that observed on other Caribbean reefs (Table 3). Only the thin dark line and inter-polyp sediment bundles signs showed higher values on PM, where major disease or syndrome effects had been expected. However, at present it is unclear if these signs are originated by a pathogen and if they directly cause mortality or are only indirectly associated with it.
Our results cannot resolve if some of the patterns observed pertain more to one of the 2 species involved, Montastraea annularis or M. faveolata. While the thin dark line seems to affect both species equally, preliminary observations (Santavy et al. 1999) indicate that the yellow-band syndrome is apparently more prevalent in large colonies of $M$. faveolata than on $M$. annularis; however, this trend is not clear in small colonies $\left(<25 \mathrm{~cm}^{2}\right)$ which were abundant on reefs surveyed. Also, our observations are basically static and given the longevity of Montastraea colonies, the potential population effect of the diseases and syndromes would have to be addressed in terms of the turnover rate of the species. Even if a disease would take longer to kill one colony of $M$. faveolata than one of $M$. annularis (or vice versa), the population effect would be similar if the mortality rate is faster than recruitment. This is probably the case of the white-band disease, as apparently Acropora cervicornis has been more severely affected (or more quickly affected) by it than $A$. palmata in the Caribbean basin.

The absence of significant differences in the prevalence of coral diseases or syndromes in reefs in different geographical settings and with different environmental stressors contradicts the hypothesis that local environmental degradation may mostly explain the prevalence of coral diseases or syndromes. Rather, it suggests a complex cause-and-effect situation that may mask local effects arising from external factors; a situation which may be further complicated by our crude approach to assessing the environmental quality of each reef.

It is a common practice to deduce reef environmental quality from the proximity of reefs to point-sources of pollution and disturbance, when environmental quality data is absent. Nevertheless, our results suggest that this approach alone may be a poor indicator of the environmental quality of a reef, at least when the reef flushing rate is high. Roberts (1974) and Wolanski \& Pickard (1983) among others, have shown that open-

Table 3. Montastraea annularis species complex. Prevalence of yellow-band syndrome on several Atlantic reefs. n: sample size; nd: no data

\begin{tabular}{|lrrrc|}
\hline Site & Year & $\mathrm{n}$ & Affected (\%) & Source \\
\hline Panamá & 1996 & nd & $0-5$ & Santavy et al. (1999) \\
Curacao & 1997 & nd & 22 & Green \& Bruckner (2000) \\
Grenada & 1997 & 2607 & 18 & Cervino et al. (2001) \\
St. John & 1997 & 2899 & 40 & Cervino et al. (2001) \\
Turks + Caicos & 1997 & 1318 & 56 & Cervino et al. (2001) \\
Bonaire & 1997 & 6298 & 91 & Cervino et al. (2001) \\
Venezuela & 2000 & 122 & $<2$ & García et al. (2002) \\
Gulf of México & 2001 & 786 & 34 & This study \\
Mexican Caribbean & 2001 & 68 & 22 & This study \\
\hline
\end{tabular}


water reefs tend to have high flushing rates as the result of wave action and tides. In this situation, the distribution and relative concentration of water-borne pollutants on a reef depend on its flushing rates. Flushing rates will vary from reef to reef, as well as seasonally within a reef, further contributing to non-linear relationships between environmental degradation and the potential effects of pollutants (Bythell \& Sheppard 1993, Lewis 1997, Ginsburg et al. 2001, Porter et al. 2001). Therefore, estimating the dynamics of a pollutant's residence time, either directly or through its accumulation in sediment and organisms (Smith et al. 1981, Erftemeijer \& Middelburg 1993), may be a necessary prerequisite to addressing the potential effects of pollutants on coral biota. As TE and CA are oceanic reefs and PM faces windward, we may presume relatively large flushing rates on these reefs.

Other authors also found no clear correlation between poor environmental quality and partial/total mortality of coral colonies (Lewis 1997, Ginsburg et al. 2001), since different species may react differently to the same set of stressors. Ginsburg et al. (2001) found that large colonies of the Montastraea annularis species complex had more dead surface than large colonies of Diploria species in the Florida Keys. Lewis (1997) found a positive correlation between colony size and dead surface area for Siderastrea siderea. Bythell \& Sheppard (1993) have shown that coral species are differentially sensitive to damage from different sources, and indicated that $M$. annularis suffers little damage from hurricanes, but is more sensitive to chronic (disease?) agents. Meesters (1995: in Ginsburg et al. 2001), suggested that larger colonies of the $M$. annularis species complex will tend to have proportionally more partial mortality than similarly sized colonies of Diploria species due to a slower capacity to overgrow dead surfaces.

The results of this study also indicate that local influences are minor in comparison with other external factors. For instance, it may be misleading to assume that offshore Caribbean waters are of high environmental quality and that a comparison of local versus openwaters could determine local effects. At present, it is uncertain to what extent open waters in the Caribbean may be polluted, and what sort of variability such pollution levels may have. Jackson (1997) claims that, due to modern anthropogenic activities including pollutants, siltation, fishing and coastal zone transformations, the Caribbean Sea no longer fulfils the conditions that allowed reefs to flourish in Holocene times. Indirect evidence of a regional deterioration may be the Caribbean-wide prevalence of diseases or syndromes (Harvell et al. 1999, Green \& Bruckner 2000). The ability of pathogens to cause epizootics in the Caribbean region may also be enhanced by the rela- tively high ecological connectivity of populations in the Caribbean Sea, as was demonstrated by the extremely rapid spread of the killing agent of Diadema antillarum (Lessios et al. 1984). The demise of Acroporids in the inner Gulf of Mexico reefs, presumably by the whiteband disease (Jordán 1992), also shows that the is a high connectivity potential for pathogens.

Linked to regional and local deterioration of Caribbean Sea waters, and the resultant potential effect on the spread and prevalence of diseases or syndromes, are the effects of global climate change. Global warming alone (with its concomitant increases in temperature of the sea surface) may increase the prevalence of coral diseases by lowering resistance to infections through direct heat-stress (Harvell et at. 1999), lower metabolic rates in corals affected by nonlethal bleaching (Harvell et al. 2001), and/or enhance the activity of pathogens (Kushmaro et al. 1996, Alker et al. 2001).

In this scenario, whereby several regional and global stressors may play an important role in degrading environment quality, the lack of definite patterns in our data on the prevalence of diseases or syndromes is not surprising. Nevertheless, our ability to successfully evaluate the potential effect of external factors on coral diseases is much restricted by our limited understanding of the pathogen host interactions for different species and coral-reef environmental conditions (Harvell et al. 1999, Alker et al. 2001). For instance, diseases such as black-band, dark spot and yellow-band, have complex etiologies that include pulse-spreading, discontinued proliferation and even healing of formerly diseased corals. Therefore, a much better understanding of the mechanistic processes of infection and mortality caused by pathogens, as well as properly designed surveys able to address the population and meta-population effects of diseases/syndromes are required to formally address the extent of disease threat to coral species.

No direct linkage was found between environmental quality and disease/syndrome prevalence in the reefs surveyed. Despite differences in geographical location and environmental stressors, each coral disease or syndrome had a similar prevalence on all 3 reefs. Our results suggest that the lack of correlation between local environmental quality and coral disease prevalence, and/or partial mortality of colonies may be partially explained by high flushing rates and low residence times of pollutants, and that regional (degraded water quality) and global (warming of superficial waters) environmental degradation in the Caribbean may already be sufficiently advanced to partially explain the prevalence of some coral diseases/syndromes.

The relatively strong prevalence of the yellow-band syndrome in colonies of the Montastraea annularis 
species complex in geographically separated reefs, subject to a different set of apparent local stressors is of great concern. Further spreading of this potentially lethal infection may result in a population decline of these key species, as has already occurred for Caribbean acroporid corals, putatively due to whiteband disease.

Acknowledgements. The following people are warmly thanked for assisting in this work: G. Jordán and H. Solís for their continuous collaboration at different stages of this work; E. Martin, F. Negrete, C. Barradas C. Meiner, L. Filip, F. Cat and E. Torrens, for their assistance with the field work, and F. Escobar, who contributed to the fieldwork logistics. A. Banaszak, P. Blanchon and three anonymous reviewers are thanked for valuable comments that improved the manuscript. This study was partially funded by PEM-PEMEX and by ICMyL-UNAM, both through direct funding and by providing us with ship time on the BO 'Justo Sierra'.

\section{LITERATURE CITED}

Alker AP, Smith GW, Kim K (2001) Characterization of Aspergillus sydowii (Thom et Church), a fungal pathogen of Caribbean sea fan corals. Hydrobiologia 460:105-111

Antonius A (1981) The 'band' diseases in coral reefs. Proc 4th Int Coral Reef Symp 2:7-14

Aronson RB, Precht WF (2001) White band disease and the changing face of Caribbean coral reefs. Hydrobiologia 460:25-38

Bruckner AW, Bruckner RJ (1997) Outbreak of coral disease in Puerto Rico. Coral Reefs 16:260

Bruckner AW, Bruckner RJ, Williams EH Jr (1997) Spread of a black-band disease epizootic through the coral reef system in St. Ann's Bay, Jamaica. Bull Mar Sci 61:919-928

Brown BE (1997) Coral bleaching: causes and consequences. Coral Reefs 16:129-138.

Bythell J, Sheppard C (1993) Mass Mortality of Caribbean Shallow Corals. Mar Pollut Bull 26:296-297

Cervino J, Goreau TJ, Nagelkerken I, Smith GW, Hayes R (2001) Yellow band and dark spot syndromes in Caribbean corals: distribution, rate of spread, cytology and effects on abundance and division rate of zooxanthellae. Hydrobiologia 460:53-63

Cowen RK, Lwiza KMM, Sponaugle S, Paris CB, Olson DB (2000) Connectivity of marine populations: open or closed? Science 287:857-859

Daszak P, Cunningham AA, Hyatt AD (2001) Anthropogenic environmental change and the emergence of infectious diseases in wildlife. Acta Tropica 78:103-116

Dustan P (1977) Vitality of reef coral populations off Key Largo, Florida: recruitment and mortality. Environ Geol 2: 51-58

Dustan P (1999) Coral reefs under stress: sources of mortality in the Florida Keys. United Nations Forum 23:147-155

Erdmann G (1997) The impact of tourism on coastal areas. Geojournal 42.1:39-54

Erftemeijer PA, Middelburg JJ (1993) Sediment-nutrient interactions in tropical seagrass beds: a comparison between a terrigenous and a carbonate sedimentary environment in south Sulawesi (Indonesia). Mar Ecol Prog Ser 102:187-198

Ginsburg RN, Gischler E, Kiene WE (2001) Partial mortality of massive reef-building corals: an index of patch reef condi- tion, Florida Reef Tract. Bull Mar Sci 69:1149-1173

Gladfelter WB (1982) White-band disease in Acropora palmata: implications for the structure and growth of shallow reefs. Bull Mar Sci 32:639-643

Green EP, Bruckner AW (2000) The significance of coral disease epizootiology for coral reef conservation. Biol Conserv 96:347-361

Harvell CD, Kim K, Burkholder JM, Colwell RR and 9 others (1999) Emerging marine diseases-climate links and anthropogenic factors. Science 285:150

Harvell D, Kim K, Quirolo C, Weir J, Smith G (2001) Coral bleaching and disease: contributions to 1998 mass mortality in Briareum asbestinum (Octocorallia, Gorgonacea). Hydrobiologia 460:97-104

Jackson JBC (1997) Reefs since Columbus. Proc 8th Int Coral Reef Symp 1:97-106

Jordán DE (1992) Recolonization Patterns of Acropora palmata in a marginal environment. Bull Mar Sci 51: $104-117$

Jordán-Dahlgren E (2002) Gorgonian distribution patterns in coral reef environments of the Gulf of Mexico: evidence of sporadic ecological connectivity? Coral Reefs 21:205-215

Jordán-Dahlgren E, Rodríguez-Martínez RE (1998) Post-hurricane initial recovery of Acropora palmata in two reefs of the Yucatán Peninsula, Mexico. Bull Mar Sci 63:213-228

Jordán-Dahlgren E, Rodríguez-Martínez RE (2003) The Atlantic Coral Reefs of México. In: Cortés J (ed) Latin American Coral Reefs. Elsevier, Amsterdam, p 131-158

Kim K, Harvell CD (2002) Aspergillosis of sea fan corals: disease dynamics in the Florida Keys. In: Porter JW, Porter KG (eds) The Everglades, Florida Bay, and coral reefs of the Florida Keys. CRC Press, Boca Raton, FL, p 813-824

Kushmaro A, Loya Y, Fine M, Rosenberg E (1996) Bacterial infection and coral bleaching. Nature 380:396

Kuta KG, Richardson LL (2002) Ecological aspects of black band disease of corals: relationships between disease incidence and environmental factors. Coral Reefs 21:393-398

Lessios HA, Robertson DR, Cubit JD (1984) Spread of Diadema mass mortality through the Caribbean. Science 226:335-337

Lewis KB (1997) Abundance, distribution and partial mortality of the massive coral Siderastrea siderea on degraded coral reefs at Barbados, West Indies. Mar Pollut Bull 34: 622-627

Merino M (1997) Upwelling on the Yucatan Shelf: hydrographic evidence. J Mar Syst 13:101-121

Porter JW, Dustan P, Jaap WC, Patterson KL, Kosmynin V, Meier OW, Patterson ME, Parsons M (2001) Patterns of spread of coral disease in the Florida Keys. Hydrobiologia 460:1-24

Ravindran J, Raghukumar C (2002) Pink line syndrome (PLS) in the scleractinian coral Porites lutea. Coral Reefs 21:252

Richardson LL, Goldberg WM, Carlton RG, Halas JC (1998) Coral disease outbreak in the Florida Keys: Plague Type II. Rev Biol Trop 46:187-198

Roberts HH (1974) Variability of reefs with regard to changes in wave power around an Island. Proc 2nd Int Coral Reef Symp 2:497-512

Rützler K, Santavy DL (1983) The black band disease of Atlantic reef corals. Mar Ecol Prog Ser 4:301-319

Santavy DL, Peters EC, Quirolo C, Porter JW, Bianchi CN (1999). Yellow-blotch disease outbreak on reefs of the San Blas Islands, Panama. Coral Reefs 18:97

Smith SV, Kimmer WJ, Laws EA, Brock RE, Talsh TW (1981) Kaneohe Bay sewage diversion experiment: perspectives on ecosystem responses to nutritional perturbation. Pac Sci 35:279-395 
Sturges W (1993) The annual cycle of the western boundary current in the Gulf of Mexico. J Geophys Res 98: 18053-18068

Vidal VMV, Vidal FV, Mesa E, Portilla J, Zambrano L, Jaimes B (1999) Ring-slope interactions and the formation of the western boundary current in the Gulf of Mexico. J Geophys Res 104:20523-20550

Vukovich FM, Crissman BW (1986) Aspects of warm rings in the Gulf of Mexico. J Geophys Res 91:2645-2660

Ward WC (1985) Quaternary geology of Northeastern Yucatan Peninsula. In: Ward WC, Weidie AE, Back W

Editorial responsibility: Albert Sparks,

Seattle, Washington, USA (eds) Geology and hydrogeology of Northeastern Yucatan and quaternary geology of Northeastern Yucatan. New Orleans Geological Society, New Orleans, LA, p 23-53

Wolanski E, Pickard GL (1983) Currents and flushing of Britomart Reef lagoon, Great Barrier Reef. Coral Reefs 2:1-8 Woodley J, Alcolado P, Austin P, Barnes J, and 10 others (2000) Status of coral reefs in the Northern Caribbean and Western Atlantic. In: Wilkinson C (ed) Status of coral reefs of the world: 2000. Australian Institute of Marine Science Townsville, p 261-285

Submitted: May 31, 2003; Accepted: March 16, 2004 Proofs received from author(s): November 25, 2004 